\title{
Some Barthian perspectives on the present science-religion debate: What is the place of "natural theology" today?
}

\author{
Cornel W du Toit \\ Institute for Theology and Missiology \\ University of South Africa
}

\begin{abstract}
As an example of the context-relatedness of Barth's work, this article compares his crisis theology with Heidegger's philosophy of Being. Further examples are Barth's reaction to the modernism of his time, with its accent on rationalism (see his critique of Kant), and the influence of subjective theology. In spite of his condemnation of natural theology, Barth could make a unique contribution to the current science-theology debate. His reading of the creation story and the way he views (transcends) the literal text in order to experience the Word of God as an event through that text, is a case in point. This approach, too, is comparable with certain aspects of Heidegger's work. Barth's reaction to the natural theology of his day was equally tied to that context. His particular target was the theology of that era which he interpreted as "natural theology". To Barth, natural theology is metaphor for self-assertive, autonomous human beings who, via reason, manipulate the church, the Word and tradition.
\end{abstract}

\section{INTRODUCTION: BARTH IN PRESENT-DAY SOUTH AFRICA?}

Concepts of God and nature are dynamically variable. This demands ongoing reconsideration of them. Cosmology and natural theology have been part of human thinking since it was first recorded, and experienced a golden age in ancient Greece. The aim of this article is not to propose a new natural theology; nor does it seek to resurrect older models. It is necessary, however, to examine the extent to which nature actually does play a role in people's faith, to take note of developments in the natural sciences which put the idea of natural theology in a whole new context, to investigate the place of natural 
theology in the dynamic science-religion debate and to make room for meaningful interaction between nature and faith. Barth is examined from this perspective, as he represents a radical rejection of natural theology and proposes instead a theology exclusively based on revelation.

In studies like this one the South African context is relevant, as Barth is to this day highly regarded in South African Reformed theology; two South Africans (the theologian Wentzel van Huyssteen and the physicist George Ellis) are prominent in the global science-religion debate; and more particularly because the debate on the relations of God and nature, and of natural science and religion, has not yet taken off in South Africa, being limited to a few interested individuals.

\section{WHAT DO WE MEAN BY NATURAL THEOLOGY?}

Natural theology was traditionally seen as a means of obtaining knowledge about God from nature (physical and human nature), applying the light of human reason to reach knowledge about God's nature and works insofar as they are revealed in physical and human nature. Linked to this are the "proofs" of God's existence, as identified by Aquinas and many others after him.

In the context of Barth's thought, however, the definition must be extrapolated to the concept of autonomous human reason, which includes all human endeavours to make sense of human existence outside the realm of revelation. It therefore includes all sciences (including theology) which seek truth outside the revelation of Jesus Christ. This means that all human reasoning activities outside divine revelation constitute natural theology. Barth sees natural theology as an expression of human self-awareness and selfconfirmation (Selbstbewahrung und Selbstbehauptung) before God.

Wissink (1983:7) adds the following relationships to the problem area of natural theology: theology - philosophy; nature - grace; Christianity - other religions; Catholicism - Reformation; and others. Terms which surface in the debate range from intolerance, Pelagianism, heathendom, metaphysics and scholasticism to culture, orthodoxy, missionary work, rationality, hermeneutics and certainty. This is no exaggeration, as for practical purposes one must take into account the whole of Barth's theology in order to understand his dismissive attitude towards natural theology.

Natural theology was a minor issue in the Reformation. That the heavens declared the glory of God was not questioned until the modern period, when the interest shifted from nature versus grace, and from works versus faith, to reason versus faith and natural religion versus revelation (Wisnefske 1990:55). The problem flared up again at the beginning of the scientific revolution in the 16th century, when Kepler and Galileo declared the 
independence of science as the "book of nature", as against religion's "book of revelation". This was the start of human rationality's declaration of independence, which became typical of all natural theology. ${ }^{1}$ Cupitt (1997:112) refers to the Enlightenment's simplified version of the world:

"There was rational theology, which consisted of a body of universal truths ... and there was revealed theology, which consisted of a body of propositions that were 'above reason' and were to be believed on authority of faith."

In our day the debate on the distinction between natural, supernatural and scientific explanations of the origins of the cosmos and of life on earth is still raging. ${ }^{2}$ There was no such debate in Barth's time, or rather, it was still in its infancy. Then, nature was not an object of deliberate theological reflection. Hummel (1994:156) points out that, following Schleiermacher, theology has become a theology of the historical revelation in strict opposition to natural theology: "Seitdem hat es im deutschen Protestantismus keine natürliche Theologie im klassischen Sinn mehr gegeben .... Die 'natürlichen Theologie' wurde zu einer Art Ketzername, und damit verschwand auch die Natur als Gegenstand theologischer Reflexion."

Barth launched the natural theology debate by characterising the theology and thought of his time as natural theology. ${ }^{3}$ Undeniably the contextual circumstance of the rise of Nazism contributed to his opinion. Hauerwas (2001:168) sees Barth's Church dogmatics “... as the attempt to develop a theological metaphysics and ethics that witness to the God who is

\footnotetext{
${ }^{1}$ The human-nature dichotomy leads to dualism. "This artificial separation of man from nature (giving man a categorical spiritual dimension) which is alien to many Christians is an important reason why some scientists have disowned the Christian cosmological view" (Miller 1995:140).

${ }^{2}$ Natural theology seems to be part of our natural life, an attempt to make sense of our natural existence. It persists in our time in spite of being discounted by theologians. "Simple involvement in natural life seems to lead people to an unsophisticated assertion that there is a God" (Wisnefske 1990:93).

${ }^{3}$ The best-known example was Barth's confrontation with Brunner (his "No!") in 1934. Brunner, in a paper Nature and Grace. A contribution to the discussion with Karl Barth, took up his position as an admirer of Barth, but listed six points in which he thought Barth overstated his case. We simply name these points without discussing them, as they are mentioned by Brown (1967:79-84): 1 Image of God: Barth argues that the image of God in humans has been completely destroyed by sin. Brunner says humans are still human starting point for natural theology. 2 General revelation: Barth exalts revelation in Christ at the expense of revelation in nature. 3 Preserving grace: Saving grace, emphasised at the expense of grace at work in the creation and preservation of the universe. Brunner emphasises God's gracious preservation, which he considers a starting point for natural theology (see Calvin's idea of the preservation of the elect). 4. The divine ordinances: Barth's denial that we can see the hand of God in certain divine ordinances. A divine ordinance of preservation must be seen as a lex naturae, and therefore as pagan. 5 Point of contact (Anknüpfungspunkt): The grace of Christ has no point of contact in humans. 6 Whether grace abolishes or perfects nature (gratia non tollit naturam sed perfcit): Over-exalting grace at the expense of nature.
} 


\section{Some Barthian perspectives on the present science-religion debate}

the beginning and end of all that is". Many people perceived this as imperialist and totalitarian. "Yet without such a theology, the church would have been even more devoid of resources in its confrontation with Hitler" (Hauerwas 2001:169). This is not a very convincing reason (Bonhoeffer felt no need for it, and found his answer in precisely the opposite direction: living in the world radically and responsibly, sicut Deus non daretur), and if it really was the case, it was not very effective and certainly not a helpful approach to today's world. In my opinion the chief emphasis of Barth's reaction against natural theology should be seen as the personal threat that modernism, ${ }^{4}$ science and the somewhat independent development of theological sciences posed to Barth.

Apart from his debate with Brunner, Barth focused mainly on Christian natural theology and hardly at all on the question of natural theology in the sciences. In The readiness of man he attacked Christian natural theology ( $C D$ II/1:135). It amounts to a sermon of conversion, in which a sinful person (in this case, a theologian) is confronted with the fact that he cannot save himself (is not prepared to subject himself to God's judgment and mercy): "It involves self-denial to deny the basic idea in all natural theology ... It involves selfabnegation. And how is this possible? How can man jump over his own shadow? ... What else is the God whom he affirms he knows immediately ... but his own reflection, the hypostasising of his self-consciousness ...?" (II/1:136). Theology, or natural theology, appears to accept revelation and grace, and gives them precedence materially and formally, but behind the humility lurks a monopolising of the Word. "To be sure, the disguise of its position of monopoly is a distinctive feature of natural theology in the Church (even in Catholicism) ..." (CD II/1:137-138). Although the believer was thrown off balance for a moment by the Word which questioned him, "he has now absorbed and domesticated revelation itself" ( $C D$ II/1:139). Barth's criticism is radical - no competition can be countenanced: "If grace is alongside nature ... it is obviously no longer the grace of God ... If God's revelation is alongside a knowledge of God proper to man as such, even though it may never be

\footnotetext{
${ }^{4}$ Modernism represents the impossible possibility that we can engage in "God-talk" without knowing God, do theology without believing in God and preach the gospel without having encountered God. This was the reason for Barth's concern. Humans became knowing Subjects, submitting everything to their investigating, scrutinising and defining reason. God cannot become a study object - he is the unknowable subject confronting humans. Barth states (CD II/1:21): "As knowledge of faith the knowledge of God is just like any other knowledge in that it also has an object. We have seen that thereby the primary objectivity of God is to be distinguished - but not separated - from the secondary. But as knowledge of faith the knowledge of God is unlike any other knowledge in that its object is the living Lord of the knowing man: his Creator, from whom he comes before he knows him .... But this means that knowledge of this object can in no case and in no sense mean that we have this object at our disposal. Certainly we have God as object, but in not in the same way as we have other objects."
} 
advanced except as a prolegomenon, it is obviously no longer the revelation of God, but a new expression ... for the revelation which encounters man in his own reflection" ( $C D \| / 1: 139)$. Although Barth himself made use of the work done by colleagues and established a respectable theology, that does not gainsay this judgment:

The triumph of natural theology in the Church, described as the absorbing and domestication of revelation, is very clearly the process of making the Gospel respectable. ... What is all open unbelief, and how hopeful it seems, compared with a "victory of faith" in which man has already conquered faith by being a believer along with all the other things he is, by making even the Gospel into a means of his self-preservation and self-defence! We can make only a brief reference to the abundance of religious, moral, political, philosophical and scientific forms in which this can take place.

$(C D \| / 1: 141)$

Barth says that natural theology usually starts from nature, "... from the nature which he has not lost even as a Christian, but which he still puts into effect as a Christian in a way which is particularly triumphant and formally conclusive; that is to say, by domesticating the Gospel, which is to make it innocuous ... . It is in its naturalness, i.e. respectability, that it has its indestructible glory" ( $C D$ II/1:142).

\section{BARTH'S POSITION ON NATURAL THEOLOGY AS THE NECESSARY CONSEQUENCE OF HIS THEOLOGICAL MODEL}

While Heidegger criticised natural theology on the basis of the nature of Being ${ }^{5}$ and philosophical insights, Barth criticised it from the position of the theology. ${ }^{6}$ His crisis theology developed into a theological model intended to immunise God, revelation and theology against any rational criticism or scientific investigation. There is almost no aspect of Barth's theology that does not impact, directly or indirectly, on his opinion of natural theology. We cite only a few examples.

\footnotetext{
${ }^{5}$ This is not the place to go into Barth's distinction between analogia entis and analogia fidei. He describes analogia entis (natural theology) as follows: "... you acknowledge an analogy between God and man, and therefore one point at which God can be known even apart from His revelation. That is to say, you acknowledge the analogy of being, analogia entis, the idea of being in which God and man are always comprehended together" (CD II/1:81).

${ }^{6}$ Chung (2005:66) has shown that, like Heidegger, Barth also rejects an unlimited mastery of human technology over the earth. Providence, which means co-existence for Barth is in fact his theological actualization of analogia relationis.
} 
Barth's theological model is so effective that it could be said to have colonised the theological world. After Barth, it was practically impossible to work outside his model without opening oneself up to his criticism. Just as the criticism of metaphysics in philosophy brought an end, de iure, to philosophy, so Barth's ideas brought an end to theologising as an independent discipline. Gauchet (1997:34), for example, responds as follows to the idea of God as the Ganz Andere (Wholly Other), which removes God as an object of modern thought because people cannot know God but can only be known by God the Subject: "The more God is thought of and venerated as the Wholly Other, the less his creatures' existence is perceived and treated by them as being controlled by something other ... Emphasising divine difference proves to go hand-in-hand with broadening the power humans have over themselves and the order they comply with." Barth has been accused of deism and dualism because of his emphasis on the Ganz Andere. In the words of Torrance (1970:122):

The achievement of this distance or separation of the divine from the human led Barth to conceive the relation between grace and nature, revelation and religion, in such a dialectic and diacritical way, that he could be trapped into speaking of God as everything and of man as nothing, which appeared to cast such a slur upon the creation that he was accused of Marcionism as well as deism.

Torrance (1970:122) ascribes this to the Lutheran and Augustinian dualism in which Barth's theology is rooted. Barth did indeed try to break free from this dualism by establishing a "positivistic theism", to such an extent that Blumhardt speaks of an "astounding and unheard of objectivity in the matters of God" (cited in Torrance 1970:123).

With reference to the way Barth deduces theology from revelation, McGrath (2003:140) says: "There is an inherent circularity within the dogmatic method, in that it ultimately rests upon a "self-positing and self-authenticating Word of God", which explains but is not explicable, and which authenticates without being authenticated." For that reason Barth's theology is classed as revelatory positivism and Christ-centred monism which, if taken literally, must of necessity isolate theology from the world and all other disciplines.

Barth remains within the framework of scientific rhetoric when he explains that, like any other scientist, he is led by his field of investigation. If theology's field of investigation is - exclusively - God, and if positive knowledge of God is obtained from the way God makes himself known, then it is impossible to use another field of enquiry (nature) as a clue to understanding God. Barth therefore makes much of the epistemological 
implications of the doctrine of sola gratia. Scientific objectivity and theological truth converge in the doctrine of justification (Torrance 1970:127-128).

In $C D$ IV/3 the first half, Barth proposes indicates the positive aspects of nature: "To the faithfulness of the Creator, ... there corresponds the persistence and constancy of the creature." $C D I V / 3$ the first half); and further: "... nature ... has its also as such its own lights and truths and therefore its own speech and words." $C D$ IV/3 the first half, 139). This testimony from nature is independent from human recognition, and not extinguished by human corruption. Nature remains the theatrum gloriae Dei (CD IV/3 the first half, 140). The light of nature points to the laws we detect in nature (CD IV/3 the first half, 142) and Barth then continue to give some characteristics of the light of nature $(C D \mathrm{IV} / 3$ the first half, $143 \mathrm{ff})$.

\section{BARTH'S STANCE ON NATURAL THEOLOGY IN VIEW OF THE INFLUENCE OF KANT AND HEIDEGGER}

\subsection{Kant's opinion on the (im)possibility of knowing God}

To understand Karl Barth's radical rejection of natural theology, we must consider his particular circumstances and contemporaries. ${ }^{7}$ We confine ourselves to Kant and Heidegger.

In Kant's thinking, God is not an object of knowledge open to human investigation. His reasoning is, of course, different than that of Barth, as Kant does not deem God to be empirically accessible to the senses and therefore knowable. God's sole significance is to further our understanding of nature or as a postulate in moral thought. As Wisnefske (1990:51) says: "For much of theology after Kant, 'God' is defined by the function it served in consciousness: it is whatever makes possible a feeling of absolute dependence; it is whatever conditions authentic existence. Whatever fills a certain function in human experience, or conditions certain activity, is 'God."' The notion of reason as the only reliable source of knowledge was increasingly to come under fire. Torrance (2004:211) says: "Until the emergence of Kant's Critique of pure reason it was reason that depicted man as the image of God. Kant challenged the capacity of reason to deliver knowledge of God and substituted reason with the ethical, the sphere of moral will as home of religion".

\footnotetext{
${ }^{7}$ Barth's theological endeavours cannot be understood in isolation from the assault they triggered on 19th century theology, although the conflict was not defined until 1929-1930 (see McGrath 2001:268).
} 
Wisnefske (1990:51) indicates that after Kant God could no longer be an object of direct human knowledge, but only "an idea of ours, useful for our understanding of nature, or a postulate of our moral activity. God therefore served human endeavor". Kant (2002:46) says:

\begin{abstract}
Thus the worth of all objects to be acquired through our action is always conditioned. The beings whose existence rests not on our will but on nature nevertheless have, if they are beings without reason, only a relative worth as means, and are called things; rational beings, by contrast, are called persons, because their nature already marks them out as ends in themselves, i.e., as something that may not be used merely as means ....
\end{abstract}

If Kant speaks out against the objectification of the other for our own benefit, this would apply even more to the objectification of God. God, however, is an object not of empirical knowledge but of religious knowledge. Similarly, Rorty (1980:382; see also 383ff) says that what is laudable about Kant is not his "epistemological" distinction between the transcendental and the empirical standpoints, but rather his "existentialist" distinction between people as empirical selves and as moral agents.

Barth had to separate the Christian God from the God of philosophers or the God of experience and thought. The only way to do this was to refuse to acknowledge God as an object of human thought, experience or investigation. ${ }^{8}$ God cannot be known without his revelatory initiative, neither can he be experienced outside it. If God in his mercy makes himself an object of knowledge in Jesus Christ, then and then only can he be known. Barth (1973:275) Summarised Kant's view in his Protestant theology in the nineteenth century: "So far as the objects of intuition and the understanding, of empirical knowledge, are concerned, God, Freedom and Immortality are not objects of our knowledge. That means: they are not objects of our theoretical knowledge. They are not to be comprehended simply as existent reality. Metaphysics - metaphysical cosmology, psychology and theology - is impossible, if one understands by it a theoretical knowledge of objects, the concepts of which must be devoid corresponding intuitions." Barth (1973:273) understood the implications for theology: "From now on theology would no longer be able to formulate its tenets, no matter on what foundation it might base them, without having acquired a clear conception of the method of reason, which it also uses in the construction of its tenets."

\footnotetext{
${ }^{8}$ This, of course, is not how human thought works. We do not think about God only when his word addresses us. In our naive experiential world, we experience God differently.
} 
Interestingly, Barth's criticism of natural theology is in fact more like criticism of rationalism and epistemology, and has little to do with nature or with knowledge of God. In Barth's terms it would be disastrous for theology if discourse about God was made possible and determined by human abilities. That would be to confirm Feuerbach's theory of God as a human projection. Barth assumes that any natural theology necessarily tries to choke out Christian theology otherwise it is not natural theology (Wisnefske 1990:53, 54). This, however, is simply a caricature of natural theology and all human culture.

Don Cupitt (1997:58) reminds us that much of our "absolute presuppositions" (our Platonic legacy) surfaced between Descartes and Derrida. Kant tried to show that some could be proved, but only by giving up the old metaphysics of God: "Instead of being objective truths propping up an objective God, Kant made them into just structural presuppositions and postulates of our knowledge and our moral action." Cupitt (1997:81) proposes a "non-realistic" view of God which asks us to give up the old "objective" doctrine of God, and instead regard talk about belief in God as a guideline for the way we see ourselves and shape our lives.

Some of the consequences of Kant's philosophy are that many people dropped a rationalist objectification of God, and moved the Platz Gottes from reason to experience and human emotion. Post-Kant, much theological writing has defined "God" in terms of his function in human consciousness: God is whatever makes possible a feeling of absolute dependence; God is whatever conditions authentic existence. This makes it impossible to distinguish God's activity from a process of consciousness, and consequently modern theology is an easy target for Feuerbach's charge that God is a projection of human feelings. Barth's reaction to Schleiermacher and existentialism was a result of his rejection of any attempt to view consciousness or feeling as a locus for knowledge about God.

\subsection{Barth's view of natural theology and Heidegger's ontology}

To understand Barth's implacable opposition to natural theology it is helpful to consider a contemporary philosopher like Heidegger, who shares Barth's attitude to natural theology from a philosophical position. ${ }^{9}$ In the 1920 s both Barth and Heidegger reacted to the postwar crisis of European culture. Barth focused on the evangelical Christian community, turning the religious rhetoric of the time on its head, while Heidegger's ontological rhetoric on the meaning of being was aimed at the existentialist community. Both were responding to

\footnotetext{
${ }^{9}$ Other thinkers like Nietzsche and the theologian Kierkegaard, not discussed here, followed the same approach. For a discussion of Kierkegaard's position, see Connell (1999:159-164).
} 
the spiritual crisis which followed the First World War: "Each of them invites the reader to understand the crisis metaphorically. Barth figured the human situation as the crisis of human sinfulness before God. Heidegger understood the situation as the crisis of inauthentic being in the world" (Klemm 1987:447). Eighteenth-century optimism in the afterglow of the Enlightenment had disappeared, and Barth silenced investigative reason by denying that God could be an object of thought. Theology as positive knowledge of God was impossible. The only knowledge of God came from God himself when He, freely and mercifully, broke into human reality - and this was not available to humans: "If this 'breaking in' does not occur, our thought remains merely empty, formal, critical and unproductive, incapable of mastering the rich world of appearance and of apprehending each particular thing in the context of the whole" (Barth 1972:48). In the words of Klemm (1987:448), "Theology thus receives a negative knowledge of God: theology knows God as wholly other than reason or unreason, language or silence, subjectivity or objectivity, and wholly other than the mediation of any of these." Logically, then, natural theology is situated within human reason; it strives to move from bottom to top (a bottom-up approach), and in Barth's opinion it is just as taboo as any other attempt to know God by rational means. ${ }^{10}$

Heidegger highlights the crisis metaphor in the inauthentic (uneigentliche) life (Dasein). Humankind has been subjected to the fallen state (Verfallenheit) of Dasein. Dasein includes guilt and death: "Die Sorge birgt Tod und Schuld gleichursprünglich in sich" (Heidegger 1976:306). Human Dasein is characterised by truth (being) and untruth (concealment), and people have no control over the appearance of being in the mode of enlightening truth any more than they have, in Barth's opinion, control over God. ${ }^{11}$ God, the Ganz Andere, breaks into human existence freely and mercifully; likewise, for Heidegger truth breaks into human Dasein. Conscience identifies authentic Dasein, and is rooted in its openness: "Das

\footnotetext{
${ }^{10}$ The distinction between the "from below" and "from above" approaches is relative and reductive. Nothing comes entirely from either "below" or "above". The metaphysical presuppositions in any natural theology, the a priori presuppositions in scientific models, the value systems in "the neutral, value-free practice of science" have all been debunked repeatedly. Barth's theology is not exclusively "from above". Any theology is embodied in the language, imagery and context of its time. Barth's rejection of the idea that God finds a human point of contact is a metaphysical statement in the service of his ideal: to disallow on a human level any possibility of knowing God. We use this distinction with the stated reservation in mind.

11 "Die existenzial-ontologische Bedingung dafür, dass das In-der-Welt-sein durch >>Wahrheit $<<$ und $>>$ Unwahrheit<< bestimmt ist, leigt in der Seinsverfassung des Daseins, die wir als den geworfen Entwurf kennzeigneten. Sie ist ein Konstitutivum der Sorge" (Heidegger 1976:223).
} 
Verstehen des Gewissensrufes enthüllt die Verlorenheit in das Man. Die Entschlossenheit holt das Dasein auf sein eigenstes Selbstseinkönnen zurück. Eigentlich und ganz durchsichtig wird das eigene Seinkönnen im verstehenden Sein zum Tode als der eigensten Möglichkeit" (Heidegger 1976:307).

As we have seen, Heidegger shared Barth's negative feelings about natural theology. Natural theology is concerned with ontologically causal, technological thinking, which is diametrically opposed to the nature of faith and being. It destroys what it seeks to prove. Connell (1999:152-156) identifies five objections which Heidegger has to natural theology. Firstly, theistic arguments are useless to express humans' relationship with God and to interpret it theologically. The fact that theology is rooted in faith makes natural theology impossible. Faith excludes any natural theological proofs. Secondly, theistic arguments are hypocritical in that believers claim to be questioning God's existence, whereas they actually accept it as true. For the same reason, believers are incapable of posing genuinely philosophical questions like "why is there something, and not nothing?" To believers, philosophy is nonsense! Thirdly, theistic arguments provide ontological reasons for ontological questions. The being of entities is not itself an entity. "To try to answer ontological questions - questions of why what-is is and why it is meaningful - in terms of a particular entity, even when that entity is God, is worse than useless" (Connell 1999:154). Fourthly, theistic arguments are causal, deducing the existence of God as the cause of specific observed effects. Their causal nature helps to obscure being. "What is more, the very god they infer is part and parcel of this desolate condition" (Connell 1999:154). Finally, the God whose existence is deduced by means of theistic arguments is a false god. Interestingly, Heidegger does not think that ontological causal thinking is necessarily flawed - only that it leads to the god of metaphysics instead of to the true God. The god causa sui is the god of philosophy, not the God before whom mankind falls to its knees in awe (Connell 1999:155). ${ }^{12}$

\footnotetext{
${ }^{12}$ Heidegger's positive response to Nietzsche's verdict that God is dead should be seen in this context: "The pronouncement 'God is dead' means: The suprasensory world is without effective power. It bestows no life. Metaphysics, ie, for Nietzsche Western philosophy understood as Platonism, is at an end. Nietzsche understands his own philosophy as the countermovement to metaphysics, and that means for him a movement in opposition to Platonism" (Heidegger 1977:61).
} 


\section{BARTH'S VIEW OF THE POSSIBILITY OF THEOLOGY AS A SCIENCE AND THE PLACE OF NON-THEOLOGICAL SCIENCES}

Barth's negative attitude to the role of the natural sciences in theology is important, because people today view nature through the lens of natural science. Barth wanted at all costs to preserve theology's independence from all other sciences and from any kind of natural theology. ${ }^{13}$

Barth set theology as a science apart from the other sciences. "If theology allows itself to be a science, it cannot at the same time take over the obligation to submit to measurement by the canons valid for other sciences." Theology could not set its own standards for science (which included good theology). "To put itself in a systematic relationship with the other sciences, theology would have to regard its own special existence as fundamentally necessary. That is exactly what it cannot do. It absolutely cannot regard itself as a member of an ordered cosmos, but only as a stop-gap in an unordered one" (CD l/1:9). Barth saw the consequence of any attempt to establish theology as a science as "... in fact destructive, (the) surrender of theology to the general concept of science ..." (CD l/1:9). He goes on to say that theology can only be a science if it spells out precisely what it understands as "scientific nature". His scorn of the sciences is evident in these words: "No science possesses manorial rights to the name of 'science', nor is there any theory of science with final authority to give or to withhold this title" (CD l/1:10).

Barth grants scientific status to theology, because in that way theology as a human attempt (a "bottom-up" one - CWdT) to find truth will have solidarity with other sciences in their own search for the good (note the humility intrinsic to scientific endeavour). Theology does not intend to leave the concept of science to the other sciences, and for that reason Barth objects to what he calls the "'heathen' general concept of science". This means that the sciences are human constructs of reality, whereas theology cannot design a construct of God to suit itself. Theology as a science is therefore a fait accompli, because God has revealed himself to humankind. In the words of McGrath (2003:139): "For the early Barth, one of the most dangerous threats faced by the church was the subversion of its own identity through the

\footnotetext{
${ }^{13}$ Barth intends a fortiori to exclude theology from science. Like other sciences, aetiology must be guided by its object of study. In order to explain what he means by science, he quotes Heinrich Scholtz's six postulates: (1) the proposition postulate (freedom from contradiction); (2) the coherence postulate (unity in the objective realm); (3) the controllability postulate (all propositions must be testable); (4) the congruity postulate (concerning that which is physically and biologically impossible); (5) the independence postulate (freedom from all prejudice); (6) it must be possible to break all propositions down into axioms and theorems, and test them on that basis (CD I/1:7-8). Barth rejects the last five, and only accepts the first on certain conditions. For a discussion of this, see Clark (1963:52-75).
} 
intrusion of 'religion' as a human construction, leading to the dislodging of the gospel itself." This implies that theology as a human construct is the same as natural theology. Nevertheless, Barth does not consider the heathenish appearance of the sciences so serious that theology has to dissociate itself from them - rather, he proposes that the sciences should be brought under the church's umbrella! (This is not to say that he supported the development of something like a Christian science $-C D \mathrm{l} / 1: 10-11$. See also Clark 1963:7174.) We could just as readily understand that any natural theology should also be brought under the church's umbrella, as all the disciplines, including theology, form part of the created realm, and can only arrive at truth through God's gracious gift of faith.

\section{THE POSSIBILITY OF KNOWING GOD}

Barth relativises any capacity for human knowledge, methodology or language-based knowledge when it comes to knowledge of God. In this regard, language, rationality, science, theology, philosophy or any other human capability have as little chance of acquiring knowledge of God as does natural theology. It would be wrong, therefore, to single out natural theology as the one and only way by which God cannot be known. God cannot be known by means of any theology, human piety, rational intelligence, science or methodology. The only way to know God is through faith, as a hidden God. Paradoxically, there is a difference between knowledge of a hidden God and the impossibility of knowing the (hidden) God. God's hidden nature is qualified:

... nothing can be more misleading than the opinion that the theological statement of the hiddenness of God says roughly the same thing as the Platonic or Kantian statement, according to which the supreme being is to be understood as a rational idea withdrawn from all perception and understanding .... For on this view God is understood as a rational idea, which, however transcendent, is general, "pure" and non-objective.

$(C D \| / 1,183)$

At the beginning of this volume he puts it like this: "We cannot equally well ask about the knowledge of the World-Ground or the World-Soul, the Supreme Good or Supreme Value, the Thing in itself or the Absolute, Destiny or Being or Idea, or even the First Cause as the Unity of Being and Idea, as we can ask about knowledge of Him who in the Bible is called God and Lord" (CD II/1:6).

God can only be known via the faith which He Himself gave to humans through revelation, a faith characterised by judgment and mercy. God gives 


\section{Some Barthian perspectives on the present science-religion debate}

this faith only by way of revelation. The question is whether faith as a human capability (or starting point for divine revelation) is not also a God-given capacity of human beings (the human creation) ${ }^{14}$ analogous to reason, science, language ${ }^{15}$ and emotion ${ }^{16}$ The answer will be that faith - as a human capacity, like language, reason and emotion - must be distinguished from faith instilled by God (since heathens or believers in non-Christian religions also have faith). ${ }^{17}$ Thus Barth sees God-given faith as a separate metaphysical gift to humankind, to be understood metaphorically as the process which takes place in the case of the elect, ${ }^{18}$ who receive a new life in Christ "from above" through the proclamation of the revealed word. But faith is not an independent human ability or capacity. What is more, "to speak of Him in our human words, this in no sense means that our human viewing, conceiving and speaking possess their own capacity for God - even a capacity awakened and actualised by revelation and faith" (CD II/1:194). What we say about God, whatever images we use, cannot be true if God does not make it true. "It is settled that as such our images of perception, thought and words neither are nor can be images of God. They become this. They become truth. But they do not do so of themselves; they do it wholly and utterly from their object. Therefore the hiddenness of God remains" (CD II/1:194).

We cannot give God a name ( $C D$ III/1:187); we cannot even know him as the eternal one. "We must not, therefore, base the hiddenness of God on the inapprehensibility of the infinite, the absolute, that which exists in and of itself, etc. For all this ... is the product of human reason." Hence any use of or reference to God outside the context of faith is meaningless. "If we incorporate Him into any of our worldviews, it may help us to complete this worldview; but

\footnotetext{
14 "The fact that we are created in the likeness of God means that God has determined us to bear witness to His existence in our existence. But it does not mean that we possess and discover an attribute within ourselves on the basis of which we are on a level with God" ( $C D$ II/1, 188).

15 "The sufficiency of our thought-form, and of the perception presupposed in it, and of the word-form based on it, collapses altogether in relation to this God" (CD II/1:190).

16 "And again, it would be a misunderstanding of the Deus definiri nequit if theology and proclamation tried to renounce the viewing and conceiving of God Himself in order to become a theology and proclamation of the subjective feelings and experiences of the pious man or a theology and proclamation of the underlying feeling of 'absolute dependence"' (CD II/1:193).

${ }^{17}$ Faith as a leap in the dark or sacrificium intellectus is similarly a human strategy. "The sacrificium intellectus as the last despairing, audacious act of self-confidence, in which man thinks he can decide upon his very knowledge of God, has turned out to be a bit of conjuring .... Even interpreted as a leap into faith, it does not create a position which cannot be attacked and is not attacked" (CD II/1:9). It would be the same as, for instance, a religious philosophy of authority.

18 "The revelation of God is that God has given to the creature whom He has chosen and determined for this end ..." (CD II/1:199).
} 
at the same time it will reveal its godlessness ... We are not master of God, and for this reason we cannot apprehend Him of ourselves" (CD II/1:189).

Revelation and faith are miracles by means of which we can understand the incomprehensible ( $C D \| / 1: 197)$. The gift of faith should be understood metaphorically, as the following point illustrates: although Paul battled to establish the idea that we can only be saved by faith in Jesus Christ (by the gospel, not the law), and although Luther had to rediscover this truth and confirm it in the context of the Catholic theology of his time, in Barth's time this idea was self-evident in Reformed circles. Nevertheless modernism and, in theology historical, editorial and textual criticism, have made faith something of a human propensity. ${ }^{19}$ Barth radicalises faith afresh by seeing it as a gift "from above", and strips all human thought, language, rationality, science, natural theology and so on, from the capacity to know God. Just as, in Reformed doctrine, people are unable to save themselves, so they cannot be saved by "faith alone" if this faith is seen, directly or indirectly, as a human instrument to ensure salvation in the context of theology, science, philosophy, language, emotion, piety or any other human capacity. Reason (Descartes) and faith alone (Luther) led modernism to false, foundational certainties (see Du Toit 2006:208). These certainties have been eroded by postmodernism and post-foundationalism.

But Barth, too, broke them down. Just as theological modernism had reached a certain prominence, Barth proclaimed the "impossibility" of theological thought and put an end to theology as an independent science (alongside but not subject to the Word). In a typically dialectical way, Barth with qualifications - restored to theology the ability to know which he had denied it. Even natural theology was restored! Barth speaks of the natural theology and natural revelation deduced by the church fathers from the relative "viewability" and conceivability of God that are granted to mankind. $\mathrm{He}$ permits natural revelation, provided it is not regarded as a human capability.

This revelation [the natural revelation and natural theology of the fathers - CWdT] occurs in the sphere of the creation of God, but not in the power of the creation as such ... [It is in the dispensation of Jesus Christ] that God - sicut mihi es - becomes knowable and therefore viewable and conceivable to us. If, in view of these creaturely dispensationes, we for our part venture and are permitted to venture to speak of God in our human viewings and

\footnotetext{
${ }^{19}$ For this reason Barth states $(C D \mathrm{l} / 1: 33)$ that if faith is to be serious, there "... must be a conflict of faith with itself". He spells this out as a conflict of church-based (or revealed) faith with itself: "For at this point, in its opposition to Roman Catholicism and to Protestant Modernism, evangelical faith is at conflict with itself" (CD l/1:36).
} 
concepts, and therefore to make use of the possibilities given to us in our relationship to the creation in general, the legitimacy and strength of this use does not originate from a revelation proceeding from the creation, but from a revelation entering into the creation and illuminating it. The fact that the one revelation of God in Jesus Christ actually does illuminate the creation and our relationship to it, and therefore also our human possibilities of viewing and conceiving, means that we are given the authorisation and command to make use of them.

$(C D \| / 1: 200)$

The created dispensation includes all human capabilities and means, from reason to language, science and therefore also natural theology as it is understood through the natural sciences. The qualification which Barth insists on is that these capabilities should not be regarded as human achievements, but as knowledge and understanding coming from God: “... our viewing and conceiving remain absolutely behind God as their object and behind faith, which is, from our side, the power of their movement. Therefore our knowledge reaches its goal only in God himself and in faith" (CD II/1:201).

The question is whether in our post-Barthian time postmodernism ${ }^{20}$ and post-foundationalism did not achieve the same in the secular sphere! The security of knowing, the absoluteness and unity of knowledge, Archimedes's fixed point of objectivity, the fundamental security which modernism brought have all been taken away again. The difference must surely be that whereas Barth restored believers' security and firm knowledge of faith and Divine revelation "from above", postmodernism and post-foundationalism did not and did not want to, since their objective was not the church and theology or a soteriology, but human knowledge systems.

\section{THE SACRAMENTAL DIMENSION OF DOCTRINE ELEVATES IT ABOVE NORMAL RATIONALITY (NATURAL THEOLOGY)}

In Christ, God is genuinely present on earth without loss of his divinity, because the person of Christ is not anchored in his humanity (anhypostatos)

\footnotetext{
${ }^{20}$ There are of course many similarities between Barth's theology as a reaction to modernism and postmodernism's reaction to modernism. For a similarity between Barth and Derrida, see Green (1999:91-108). Barth explains knowledge of God by using an image of concealment and revelation. For Derrida, difference functions as an alternative to presence (objectivity and accessibility). In the context of difference, the sign functions as a trace which moves meaning dynamically from trace to trace in a dialectic of revelation and concealment. Barth and Derrida both make use of "the same double nature of language" (Graham Ward, quoted in Green 1999:97). As in the comparison with Heidegger, this is not to say that there are not differences as well.
} 
but has its substance in the Logos (enhypostatos). This metaphysical construct legitimises knowledge of God, human language and even natural theology, provided they are rooted enhypostatically in the Logos. The same applies to human thought, the human person, human understanding of the world and even natural theology (!), if they are anchored in the Logos. Just as faith changes bread and wine into the body and blood of Christ (though not physically observable) in the eucharist, so the human person, human rationality, language and insight change when they acquire a sacramental dimension through the revelatory Word of God. ${ }^{21}$ This enables Barth to say $(C D \| / 1: 110)$ :

The place in which revelation takes place becomes ... objectively another place by now becoming the place of revelation. Man in the cosmos, who is confronted with God's revelation ... becomes, as man confronted by God's revelation, objectively another man ... But this otherness of man is - always in the first place quite objectively - his truth, his unveiled reality: the truth and reality also of his cosmos.

Outside the "place" of the revelatory Word, human truth is falsehood, human knowledge is veiled in darkness, and the human cosmos is nothing but natural theology. Barth provides a further example of this in his explication of Psalm 36:9 ("With thee is the fountain of life: in thy light shall we see light") when he says that Israel, like its neighbours, looked to the stars and natural phenomena like storms in order to make statements about God. The difference is that insofar as Israel's statements were made "under the revelatory word", they obtained a different meaning. "It is because and as God speaks and acts in Israel that man in the cosmos becomes objectively another, namely the one who in the whole cosmos encompass of his existence can now know and has to acknowledge the might and glory of this God" (CD II/1:112). The following passage sums it up:

\footnotetext{
${ }^{21}$ God reveals himself by concealing himself in cosmic creatureliness in Jesus Christ, who is an enigma (Erde) but who also enlightens as an enigma (Welt) $(C D \| / 1: 56)$. Barth himself uses the sacrament as a token of revelation: "He unveils Himself as the One He is by veiling Himself in a form which He Himself is not. ... He uses its work and sign, in order to be objective in, with and under this form, and therefore to give Himself to be known. Revelation means the giving of signs. We can say quite simply that revelation means sacrament, that is, the self-witness of God, the representation of His truth, and therefore of the truth in which He knows Himself, in the form of creaturely objectivity" (CD II/1:52). Green, correctly in my view, says that "Karl Barth's theology can thus be accurately described as a semiology, a theological semiotics".
} 
We can now see what is involved in this remarkable biblical reference to man in the cosmos as such ... By pointing to man in the cosmos, they [i.e. biblical references - CWdT] point to a certain extent through him to the man of the revelation of God, that is to the man who, in the covenant of God with his people, in the unity of the members of the body of Christ with their Head, is a participant in ... the knowledge of God. They do not consider taking man in the cosmos seriously and addressing him in his 'nature' - which really means in his self-understanding. Rather they say to him that he no longer really exists as such; that in his self-understanding he now exists only in one monstrous misunderstanding. For his original and proper truth has now been opened up to him by God's revelation. They point to ... Jesus of Nazareth, to the judgement fulfilled in Him, to the grace which man has found before God in Him. They point to Him as the origin and future of man in the cosmos.

$(C D \| / 1: 112)$

Thus we are dealing with an event analogous to the sacramental changing of the bread and wine - an event which people readily understand as one in which the same object acquires new meaning. This was described by Heidegger (1971:15-89) in his essay "The origin of the work of art". As Erde (earth), the work of art is simply a physical, autonomous fact. At the same time it is the work of art veiled and concealed. Understanding and internalising the work, experiencing the work as an event constitutes its world (Welt). The impact of the work comes from the object itself and is not determined by the subject. Analogously to Barth's view that people under the Word find themselves in a different place and are altered in their being, Heidegger (1971:35) takes the example of Van Gogh's painting of a pair of shoes: "[Welt] comes to the fore only by bringing ourselves before Van Gogh's painting. This painting spoke. In the vicinity of the work we were suddenly somewhere else than we usually tend to be." "The art work opens up in its own way the Being of beings. This opening up, i.e. this deconcealing, i.e. the truth of beings, happens in the work" (Heidegger 1971:39). In this way our understanding becomes ontological, and not merely methodologically determined. ${ }^{22}$

To Barth, people under the revelatory word find themselves in a different place and see themselves and the cosmos unveiled. Similarly, Heidegger sees the change of Erde into Welt as an unveiling action, and sees people experiencing every day that reality metaphorically acquires new meaning. So the light fades for researchers and scientific investigators, and so people appropriate meaning in order to make sense of the world and their own

${ }^{22}$ See Du Toit (1984:48). For a detailed discussion of Heidegger's essay, see pp 43-51. 
existence. Cognitive scientists explain the process as an outcome of normal human brain functions, regardless of the area - religion, aesthetics, science or ethics - which gives rise to it. The specific "medium" (be it a metaphor, myth, work of art, sermon, film, poem or scientific model) is a matter of chance. On the secular level the experience can be interpreted as a sacramental dimension - an event which people find holy, moving, insightful, related to words and understanding.

To return to Barth, a good example of how understanding takes place can be seen in the account of creation, which Barth treats as a "creational work of art" that "opens" in order to reveal, behind the material nature of the work (as myth), the world of God's work. Barth's contribution in this regard is an excellent example that can be used to put an end to futile arguments in the science and religion debate. In his typically dialectic way, Barth states that "... the history of the covenant of grace with its miracles, and especially the great central miracle, is not only undoubtedly historical but also ... highly 'nonhistorical' ... it is not a 'historical' history ... it can be the object only of a 'nonhistorical', pre-historical description and narration" (CD III/1:79-80); “... the biblical history of creation is pure saga ... we ought not to be offended because they are sagas. We are no less summoned to listen to what the Bible has to say in the form of saga than to what it has to say in the form of address, doctrine, meditation, law, epigram, epic and lyric" (CD III/1:82-83); "the creation stories of the Bible are neither myths nor fairy tales. This is not to deny that they are myths, and perhaps in part fairy tale, in the materials of which they are constructed ...They are not a historical cover for non-historical speculation" (CD III/1:84). Discussing myths in more detail, he goes on:

... [myths] demand that they should look through the story ... How can we understand myth if we ignore this demand and do not try to meet it? Myth has always arisen and still arises from the higher recognition, divination and poetic understanding of this kind of eternal truth. It has always been a worthy alter ego for philosophy ... [myth] only appears to tell of creation but in reality it speaks of a particular view or solution of the enigma of the world; of a combination of real or supposed world-elements by which a man or an era thinks that they can explain the existence of these elements in their cyclical aspects. Never is man more himself and at home in his world, never does he have in his own strength a better understanding of himself and his world, than as an inventor and author or an intelligent hearer and reader of myths.

$(C D I I / 1: 85)$ 
What Barth says here applies specifically to natural theology, as he refers specifically to "man in his own strength". What does it mean to "look through" a myth? In Heidegger's example, it means to penetrate the art work as Erde and to experience how Welt appears from it. On the religious level, it means to hear God's word in human words. When Barth looks through the creation myth, he finds a world of creation which he deems to be literally true in a theological sense and on which he bases his entire dogmatics. This emerges from the following well-known statement: "His creation is the external basis of this covenant" ( $C D$ III/1:96). In the creation of light, which is effectively summoned from the darkness, Barth sees an analogy to the history of chosen and rejected people in the Bible (Jacob-Esau, David-Saul, Judas-Apostles) ( $C D$ III/1:123). In human beings formed in the imago Dei he first sees Christ as an image of God in which all humanity participates and where men and women reflect the I-Thou relationship between creator and creature in an analogia reflectionis, also manifest in the inter-trinitarian relationship $(C D$ II/1:194-206). ${ }^{23}$

Barth's entire theology is based on his way of looking through the biblical texts in all their multiplicity of genres as Erde to discover behind them the word of God as Welt, which addresses its dynamic appeal to humanity.

\section{CURRENT PERCEPTIONS OF NATURE (AND A POSSIBLE NATURAL THEOLOGY) VIA THE NATURAL SCIENCES}

Nature has traditionally been experienced as provident, threatening and mysterious, and its religious, romantic and aesthetic dimensions have been emphasised. Most people still find these dimensions relevant, while others can be added such as nature in its ecologically sensitive mode - especially as a source of recreation, knowledge, technological manipulation and benefits to humanity - as well as issues of ownership.

Nowadays, especially in developed countries, the religious and aesthetic dimensions of nature are mediated by the natural sciences. We never encounter "pure" nature: it always comes in a ready-interpreted form. Many people find that this does not interfere with, but intensifies, their experience of beauty, admiration and wonder.

This implies that a reinterpretation of natural theology has become essential, not as a new proof of God's existence but as a necessary dimension of the interpretation of faith in order to arrive at intellectual honesty in the modern world.

\footnotetext{
${ }^{23}$ For a concise discussion of this, and for the ethical dimension of interdisciplinary work and the connection between imago Dei and human rights, see Van Huyssteen (2006:111-165).
} 
Although many believers manage to keep the modern, scientific worldview image in a state of coordinated tension with the biblical worldview, others find this unsatisfactory, and in the absence of a public forum for discussion, implausible biblical statements are written off as myths without any attempt to incorporate them meaningfully into a modern hermeneutic system. Not every statement in the Bible is a myth, and not all myths are meaningless for the construction of values that could contribute positively to contemporary societies. The revision and explication of theological and doctrinal rhetoric are prerequisite for meaningful contributions to present-day inter- and trans-disciplinary discourse.

In Barth's terms, does this mean compromising the exclusivity of the divine revelation in Jesus Christ? I do not think so. Barth's radical view of revelation should not prevent us from, where appropriate, complementing and even reinterpreting revelation with the aid of physical, biological, ecological, health and other dicta from the natural sciences which have become part of the modern worldview. Those explanations are in no way meant to compete, on a soteriological level, with faith when it comes to the exclusivity of salvific events. Appropriating these events does not abrogate believers' responsibility towards the world they live in and the values developed with the aid of insights from natural science.

Many theologians do not suffer from a paranoid fear that theology is incapable of functioning as a scientific discipline and are ready to enter into dialogue with other sciences about joint and mutual responsibility for our world. This does not mean that the scientific voice of theology cannot address a prophetic appeal or cannot invoke faith in the course of such dialogue. Interested parties from various fields are in fact looking for possible contributions of believers from all religions in view of the problems threatening the world and its peoples. In his book on the place and role of order in theology and natural science, Torrance takes us beyond the dualistic view that natural sciences only ask 'how' questions and theology only asks 'why' questions. "That sharp distinction had the effect of importing a deep split between science and theology" (Torrance 1985:20). These questions are interdependent and inseparable - which does not mean that theology and natural science have amalgamated, though it does mean that both sides can and should influence each other so that each can make its own distinctive contribution. Torrance sees the concept of order as a common denominator which unites both disciplines: "The fact that natural and theological science both operate under the constraint of an ultimate ground of order, which will not allow a divorce of natural order from the order that ought to be, shows us that there is only one rational order pervading the entire universe" (Torrance 1985:21). Barth's dialectical rhetoric made it possible for him to transgress the limitations we impose on an enclosed worldview. In Barth's view of creation 
"any dualism between immanence and transcendence becomes superficial", confirms Chung (2005:60).

\section{CONCLUSION: A NEW NATURAL THEOLOGY?}

Does the debate between natural science and theology result in a new kind of natural theology ${ }^{24}$ The answer is yes and no. No, in that it does not posit new proofs of the existence of God (attempts at that, like certain aspects of the anthropic principle and the "natural intelligence" debate, have been criticised); and yes in the sense of Barth's opinion, because it represents something of an effort to understand. To most supporters, however, it is not an attempt which ignores the Word of God, but rather to look through words in order to see more clearly. Looking not only at words but also at physical reality is to see how the light that pours out from the cosmos is broken up by the prism of the Word to display the many-coloured spectrum of God's grace.

Taking Barth seriously does not mean attributing natural theology to a bunch of "radical" natural scientists and theologians who "go too far" in their interpretation of evolution and other natural scientific findings. The church is under threat in the first place from a Christian natural theology which is revealing itself in the form of human self-justification, self-preservation and self-defence. The real threat is self-assured fundamentalism, self-justifying foundationalism and smug, blinkered traditionalism. ${ }^{25}$ Barth gives natural theology a place on the left hand of the Word: ${ }^{26}$

\footnotetext{
${ }^{24}$ Natural theology is distinct from a theology of nature. In Barthian terms natural theology, being analogia entis, is a theology "from below", premised on human beings, their empirical observation and sciences. A theology of nature, on the other hand, is part of God's revealed word and can therefore be seen as analogia fidei. Peters (2005:2) puts it thus: "Natural theology starts with unfaith and finds in nature evidence for the existence of God. Theology of Nature, in contrast, starts with faith and interprets the natural world as God's creation." In the same vein Barbour (1997:100) writes: "A theology of nature ... starts from a religious tradition based on religious experience and historical revelation." Peters (2005:2) distinguishes a minimalist theology of nature that adapts to changes in worldview according to prior religious commitments from what he calls a maximalist theology of nature, in which God constitutes our knowledge of the natural world. I find this distinction (like the one between "from below" and "from above") artificial, for how do I know whether my experience and belief are determined exclusively by one or the other?

${ }^{25}$ We should bear in mind that Barth described church history, in particular, as natural theology. "All refutations apart, natural theology can do so much that we must seriously ask whether there is not good reason to present the history of Christian theology and the Church in general ... as one long history of 'Christian' natural theology" (CD II/1: 127-128).

${ }^{26}$ There are three witnesses: God, mankind and the cosmos. God, who speaks through his Word; mankind's witness of the power of the Word to strike them and change them, and the voice of the cosmos in all the dimensions in which we can understand and interpret it $(C D$ II/1:99).
} 
In the middle, so to speak, there stands the real prophetic-apostolic witness of God's speaking and acting in the history of Israel and in the history of Jesus Christ. But on the right there stands independently the reference to the direct confirmation by God Himself ... [through the] speaking of the Holy Spirit ... Then on the left ... there stands independently the reference to man in the cosmos: man with the ability to receive the voice of the cosmos.

(CD II/1:99-100)

How do we hear the voice of the cosmos today? I hear the voice of the cosmos (natural theology) through a modest attempt to understand what we can learn of the world and the cosmos by listening to the evidence of the natural sciences (in a science and religion debate); through an obstinate wish to interpret those insights in the light of God's word; through blatant honesty about the failure of our theories to prove the existence of God (anthropic principle, natural intelligence debate, and proofs of God); through altruistic responsibility, as a created co-creator, for the fate of God's creation (ecological responsibility and respect for life); through developments in genetic engineering; through self-relativising respect for cultural and religious diversity (religious, cultural and human rights); through understanding the fragile evolutionary process and the biological and corporeal embodiment of our thinking (physical relativising of our epistemologies); and through solidarity with the fate of all life-forms on our planet (social and ethical dimensions of faith).

In this approach to natural theology, there is a greater need of understanding than of self-justification; an acknowledgement of the vulnerability and interdependence of all forms of life on this planet; and an admission that people find meaning in value systems and personified transcendence

\section{Works consulted}

Barr, J 1993. Biblical faith and natural theology. Gifford lectures for 1991 delivered at the University of Edinburgh. Oxford: Clarendon.

Barth, K 1972. The epistle to the Romans. London: Oxford University Press.

Barth, K 1973. Protestant theology in the nineteenth century: Its background and history. Great Britain: Judson.

Barth, K 1964. Church Dogmatics, I/1: The doctrine of the word of God. Edinburgh: T\&T Clark.

Barth, K 1964. Church Dogmatics, II/1: The doctrine of God. Edinburgh: T\&T Clark.

Barth, K 1964. Church Dogmatics, III/1: The doctrine of creation. Edinburgh: T\&T Clark. 
Barth, K 1961. Church Dogmatics, IV/3. First Half: The doctrine of reconciliation. Edinburgh: T\&T Clark

Barbour, I G 1997. Religion and science: Historical and contemporary issues. San Francisco, CA: Harper.

Brown, C 1967. Karl Barth and the Christian message. London: Tyndale.

Cupitt, D 1997. After God: The future of religion. London: Weidenfeld \& Nicolson.

Chung, P S 2005. Karl Barth and God in creation: Towards an interfaith dialogue with science and religion. Theology and Science, 3/1 55-70.

Clark, G H 1963. Karl Barth's theological method. Philadelphia, PA: The Presbyterian and Reformed Publishing Company.

Connell, G 1999. Against idolatry: Heidegger and natural theology, in Westphal, M (ed), Postmodern theology and Christian thought, 144-168. Bloomington, IN: Indiana University Press.

Du Toit, C W 1984. Die metaforiese spreke oor God (The metaphoric way of speaking about God), DD Proefskrif, Universiteit van Pretoria.

Du Toit, C W 2006. Technoscience and the integrity of personhood in Africa and the West, in Shutte, A (ed), The quest for humanity in science and religion. Pietermaritzburg: Cluster.

Du Toit, C W 2006b. Secular spirituality versus secular dualism: Towards postsecular holism as model for a natural theology, in Du Toit, C W \& Mayson, C P (eds), Secular spirituality as a contextual critique of religion, 49-73. Pretoria: Unisa.

Gauchet, M 1997. The disenchantment of the world. Princeton, NJ: New French Thought.

Grau, H G 1973. The Barth-Bultmann correspondence. Theology Today Vol 30(1), 138-147.

Green, G 1999. The hermeneutics of difference: Barth and Derrida on words and the Word, in Westphal, M (ed), Postmodern philosophy and Christian thought, 91108. Bloomington, IN: Indiana University Press.

Gundlach, T 1992. Selbstbegrenzung Gottes und die Autonomie des Menschen. Karl Barths Kirchliche Dogmatik als Modernisierungsschritt evangelischer Theologie. Frankfurt am Main: Peter Lang.

Heidegger, M 1971. The origin of the work of art, in Poetry, language, thought, 15-87, tr by Albert Hofstadter. New York: Harper \& Row.

Heidegger, M. 1976. Sein und Zeit. Tübingen: Max Niemeyer Verlag.

Heidegger, M 1977. The question concerning technology. New York: Garland.

Hauerwas, S 2002. With the grain of the universe: The church's witness and natural theology. Gifford lectures delivered at the University of St Andrews in 2001. London: SCM.

Hummel, G 1994. Natürliche Theologie versus Theologie der Natur? Berlin: Walter de Gruyter.

Jeeves, M (ed) 2004. From cells to souls - and beyond: Changing portraits of human nature. Grand Rapids, MI: Eerdmans.

Kant, I 2002. Groundwork for the metaphysics of morals. New Haven, CT: Yale University Press.

Klemm, D E 1987. Toward a rhetoric of postmodern theology: Through Barth and Heidegger. JAAR 55(3), 443-469.

McGrath, A 2001 A scientific theology, Vol 1, Nature. Edinburgh: T\&T Clark.

McGrath, A 2003 A scientific theology, Vol 3, Theory. London: T\&T Clark. 
Miller, R 1995. Arguments against secular culture. London: SCM.

Peters, T 2005. Natural theology versus theology of nature. Theology and Science 3(1), 1-3.

Rorty, R (1980) 1983. Philosophy and the mirror of nature. London: Blackwell.

Torrance, A J 2004. What is a person, in Jeeves, M (ed), From cells to souls - and beyond: Changing portraits of human nature, 199-222. Grand Rapids, MI: Eerdmans.

Torrance, T F 1970. The problem of natural theology in the thought of Karl Barth. Religious Studies 6, 121-135.

Torrance, T F 1985. The Christian frame of mind. London: Handsel.

Van Huyssteen, J W 2006. Are we alone in the world?: Human uniqueness in science and theology. Grand Rapids, MI: Eerdmans.

Wisnefske, N 1990. Our natural knowledge of God: A prospect for natural theology after Kant and Barth. New York: Lang.

Wissink, J 1983. De inzet van de theologie: Een onderzoek naar de motieven en de geldigheid van Karl Barths strijd tegen de natuurlijke theologie. Amersfoort: De Horstink. 